\title{
Editorial
}

\section{Changing of the Guard}

With this September 2008 issue of College and Research Libraries there is a changing of the guard in editors and editorial board members. I assume the role of editor, replacing Bill Potter who has served in this position so ably for the past six years. Fred Hay, the journal's long-standing book review editor, turns over his responsibilities to Geoffrey Smith. We also have a new editorial support team and new editorial board members who are listed on the masthead.

While all of us involved in editorial work think we make a difference, it is really, of course, the authors and the referees who count. Our journal receives about one hundred manuscripts annually for consideration. After a quick initial review by the editorial team, ninety percent of these submissions are sent to at least two referees for blind peer review.

With the referee evaluations in hand, I accept the best manuscripts that advance our knowledge about academic librarianship. Our acceptance rate over time has been about thirty to forty percent.

Blind peer review is a time consuming and labor intensive process, but well worth the wait and effort. Our peer review, as much as it is humanly possible, is objective, and I hope also rigorous and constructive. Authors should receive back from us useful and fair critiques of their writing and ideas. Almost all authors, whether their manuscripts are accepted or rejected, receive recommendations for revisions that will make their writing stronger. Experienced authors know the secret to good writing: revise, revise, and revise again!

In the Internet Age will authors continue to write for peer reviewed scholarly journals like College $\mathcal{E}$ Research Libraries? Will busy professionals continue to volunteer their time and effort as referees to perform the essential but anonymous task of peer review? I hope so, or I will be out of an editorial job, and more seriously, I believe our profession will suffer.

Peer review offers an essential element of quality control in scholarly communications and is our basis for selecting the best writing to bring to you. It has worked in the past-helping to make College \& Research Libraries one of the most widely read and cited journals in academic librarianship. I know, however, that we cannot rest on our laurels. To dramatically reduce the time from submission to acceptance and access, we have established a pre-publication service that makes accepted peer reviewed manuscripts immediately available online to the public. You can find this new pre-publication service on the $C E R L$ Web site. We will continue to look for ways to improve the journal, making it more responsive to both author and reader needs without sacrificing our commitment to peer review.

Joseph J. Branin Editor, College E Research Libraries 